\title{
DESIGN AND EVALUATION OF SELF-CONTROL DRIPPER
}

\author{
El-Mesery A. A.* ; Z. Y. Abdellatif **; S. S. Hassan*** and
}

\section{A. A. Abd Elrasheed $* * * *$}

\section{ABSTRACT}

The present study aims to design and evaluate of Self Control Dripper"SCD"to control the water management in sand soil. The study evaluate self control dripper under different factories as rubber thickness"TH"'of 3.0, 3.5 and $4.0 \mathrm{~mm}$, sensor volume "V"of 25 and $75 \mathrm{ml}$, burial depth of 5, 10,15 and $20 \mathrm{~cm}$, water head" $H$ "40, 60, 80 and $100 \mathrm{~cm}$ and water outlet length "L" of 10, 20 and $30 \mathrm{~cm}$. The evaluation achieved by wetness radius of soil water, " $R$ " $\mathrm{cm}$, adding water" $Q$ "l and adding water time"'T"min. The results concluded that; the best size of sensor was $25 \mathrm{ml}$ and the best rubber thickness of were 3.5 to $4 \mathrm{~mm}$.The relation between mention factors and wetted radius $R(\mathrm{~cm})$ was:

$$
R=1.75\left(\frac{D^{.4144} \times H^{.38567} \times L^{.4793}}{T H^{.40527} \times V^{.06219}}\right)
$$

These results were obtained at used by ANOVA TEST.

Where: TH : Rubber thickness, $\mathrm{mm}, \quad V$ : Sensor volume, $\mathrm{cm}^{3}$,

D: Buried depths, cm, H: Operation heads, cm,

$L:$ water outlet distance, $\mathrm{cm}, R:$ Radius of wetness soil area, $\mathrm{cm}$.

\section{INTRODCUTION}

elf controller dripper is one of newest systems of clay jar irrigation system. Clay jar self controller dripper as a traditional techniques cost relatively small and when combined with appropriate modern technology, can prove extremely effect. David (2001) mentioned that the buried clay pot or pitcher method is one of the most efficient traditional systems of irrigation known and is well suited for small farmers in many areas of the world. Water seeps out through the clay wall of the buried clay pot at a rate that is influenced by the plant's water use.

* Prof. of Agric. Eng., Fac. of Agric. Eng., AL-Azhar Univ., Cairo. ** Prof. of Agric. Eng., Fac. of Agric. Eng., AL-Azhar Univ., Cairo. *** Head of Researcher, Agric. Eng. Res. Inst., (AEnRI) Agric. Res. Center. **** Postgraduate, Agric. Eng. Res. Inst., (AEnRI) Agric. Res. Center. 
This leads to very high efficiency, Buried clay pot irrigation uses buried, unglazed, porous clay pots filled with water to provide controlled irrigation to plants. The even better than drip irrigation, and as much as 10 times better than conventional surface irrigation. This method is also very effective in saline soil or when saline irrigation water must be used. It has proved useful for land restoration in very arid environments.

Ibrahim et al. (2003) using black shales associated with coal seams in Gabal Maghara (Sinai) Egypt, together with other two samples, byproduct of the coal beneficiation process namely mudcake and discard were investigated to assess their application in ceramic products. The rheological property and the firing characteristic were also studied. The samples contain appreciable amount of organic matter that proved by IR to be a mixture of aliphatic and aromatic groups. The content of clayey materials ranged between 89 and $94 \%$. The loss on ignition in the mudcake was about $39.79 \%$. The mudcake gave a porosity of about $50 \%$, an attempt to produce bricks or pipe for irrigation were carried out. Organic matter may be added to increase the porosity of the fired bodies, eg. Bricks. Ornstein (1985) in his study on a moisture-sensitive selfregulating water value for drip irrigation systems, buried this device in the soil near the plant's roots. He found that the water flow increased with the increasing of buried depth. Abdellatif (2003) studied the effect of distance"L"between the water outlet and the"SCD"on the water flow using two types of soil. He found that the"SCD"opened between two points of soil centibar in both types of soil meteric potentials: -10 and-20 centibar. He added that there is relationship between the water flow"Q", lit and the outlet length"L", cm. Also In 1985, Ornstein used the small device to control the self in the process of irrigation called (Irristat) a small device that contains within it a substance Poly Acrylamide (gel), which is voracious absorption of water where it absorbs times the size of water. This substance has placed in a disc perforated and above the piston topped tube connected to the source of water, when the device used, it buried in the soil in the root zone, but water down through capillary tube over the soil surface and when water down from a capillary tube on the soil is up to the device shall enter the gel in the absorption of water exceeded the size of pressuring the piston and thus put pressure on the tube noodles manufacturer of silicon (Silicon rubber) will prevent the descent of the water and when soil is dried water will be sucked from 
the gel decreases its volume decreases pressure on the piston will descend, opening the water and thus has been used compressor 3-10 $\mathrm{m}$ of the water source as Qatar Branch Line external 9,5 $\mathrm{mm}$ and pipe connected to the device outer diameter of $2 \mathrm{~mm}$ and inner $1 \mathrm{~mm}$. He also added that the effort of the soil at saturation is equal to zero either at the field capacity, it ranges between -5 to -30 centibar according to of the soil and found that the opening and closing of the device depends on the hydraulic conductivity coefficient as well as the distance between the exit of the water and the device has been found that the device when used in the mud that opens when tension became - 30 centibar and closes the path of water when the effort to the soil - 10 centibar, and the device in the cases of opening and closing.

The present study aims to design and evaluate Self Control Dripper"SCD"to control the water management. The design parameters which studied as volume of self controller dripper, thickens of rubber,initial head water outlet open diameter and distance between water outlet and self control dripper device.

\section{MATERIALS AND METHODS}

This study was carried out in desert of $6^{\text {th }}$ October city at 2008 season. The self- controlled drippers"SCD"(sensors) designed and manufactured by Researches and the Late Prof. Dr. Zakaraia Yones. The SCD made from a material consisted of a hydrocarbon matter as a primary material. Self controlled"SCD"is a small device which requires no power source. It has capacity to control irrigation of any plant or tree, potted or in the field, at exactly the rate required to match its physiological demands. Each"SCD"keeps the soil moisture around the root zone of its plant at the ideal level. It should help to further reduce the water wasted through the use of even the most efficient drip irrigation systems and save energy. The clay jar was manufactured in especial work shop at Kalubia Governorate. Many types of clay mixtures were tested to know the best material used in making these sensors and tensiometers. The designed"SCD"sensor as shown in Fig.(1), (1-a), (1-b) and photograph (1) consisted of three principal parts:

1. Conical shape part as a sensor made from a porous jar.

2. Two screw plastic cylinder (Teflon cylinder) to fix one on the conical shape jars and the other on the rubber membranes. The second cylinder contains two orifices (outlet and inlet) 
a- The outlet of water (connected with a tube which transmits water to the soil).

b- The inlet of water taking the water from the tank.

3. Rubber membranes above the screw plastic cylinder.

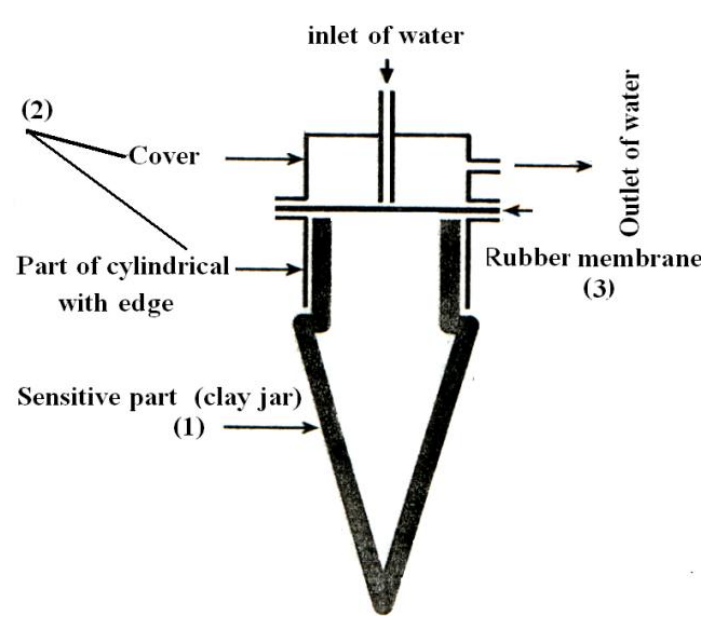

Fig.(1) Schematic diagram of the dripper

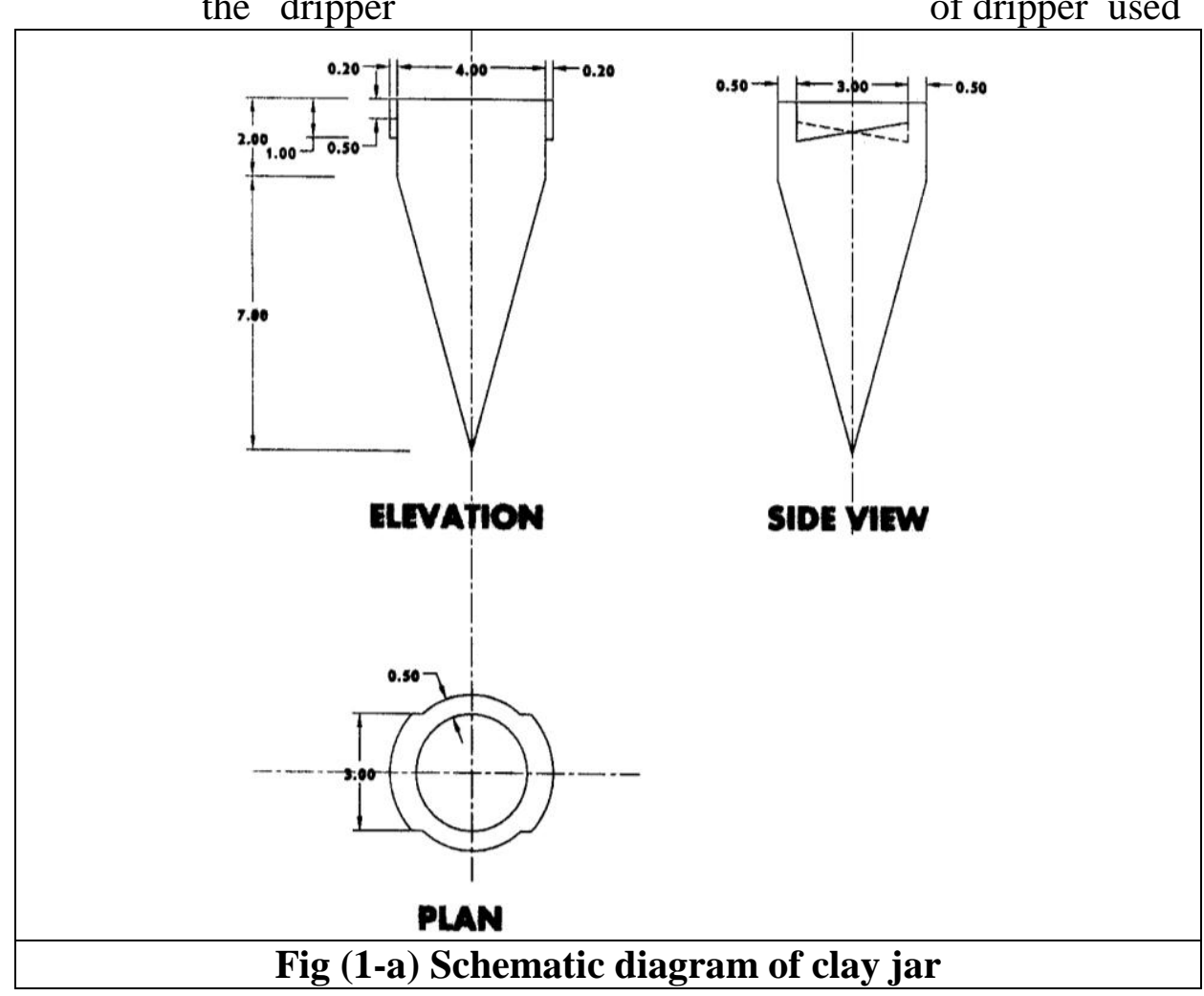




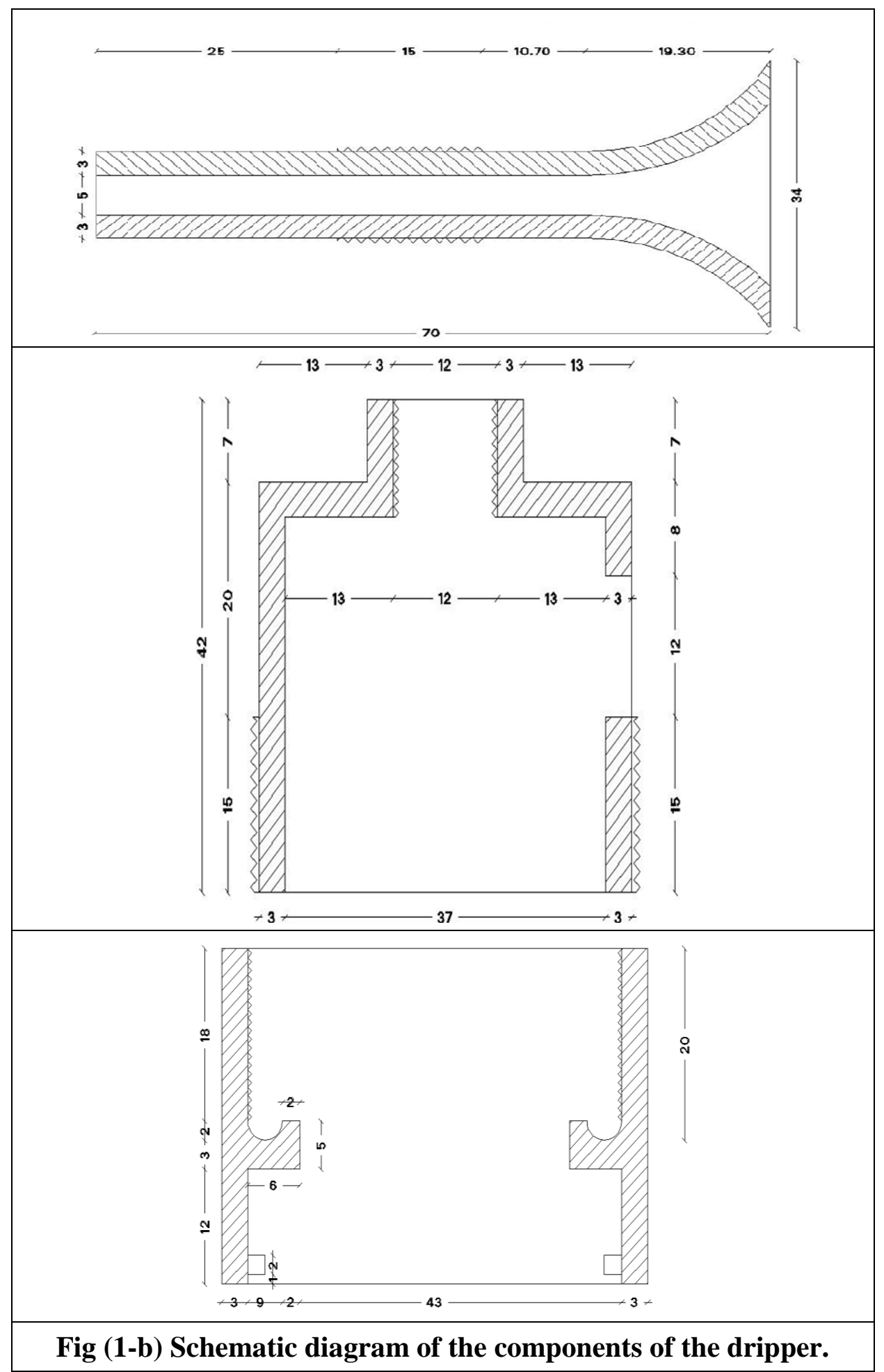

Misr J. Ag. Eng., October 2013 


\section{The experimental procedure:}

1- The manufactured dripped tested in laboratory to test the ability of clay jar used inside or outside in sensors to resist the pressure or the discharge in comparison to the atmospheric pressure. The laboratory tests were carried out in Irrigation Laboratory at Irrigation Department in Agriculture Engineering Institute.

2- The field tests carried out in $6^{\text {th }}$ October desert. At two steps:

Before working it must adjusted the dripper:

The dripper is connected with water source (tank of water always filled with water) Fig. (2-a) and (2-b). It can also connected many numbers of drippers with this tank through a lateral lines connected with the tank. Also, it is possible to use more than one tank according to the irrigated area. The dipper must operate with the following steps:

1- The clay jar fill with water, covered with rubber and closed by the screw cylinder, with very tied close.

2- The clay jar buried and fixed the soil, then connected with water tank.

3- When the soil dry, the soil start to release the water from the clay jar extract.

4- According to the soil water potential (soil metric) there is a negative water potential will produced inside the clay jar which pushed the rubber membranes downward that causing the water flow from the tank to the drippers, and finally it drop on the soil (Fig., 3a).

5- The soil absorb the enough amount of till the soil water potential decreased, then the dripper will closed, (the rubber membrane start to extend again the first position (Fig., 3b)).In this case the clay jar fill with water.

\section{The Self controlled dripper characteristics :}

The"SCD"was used at different operation heads"H"of 40, 60, 80 and 100 $\mathrm{cm} /$ water. Also it was used at different buried depths"D"of 5, 10, 15 and $20 \mathrm{~cm}$ depth. Study on self-control dripper to overcome the problem of blocking in the field.

\section{Laboratory measurement of the Dripper used.}

Before the dripper introduce to the irrigation network there were different laboratory and field experiment carried out as the following:

1 -The measurement of the dripper porosity.

2-The effect of pressure used on the dripper discharge. 


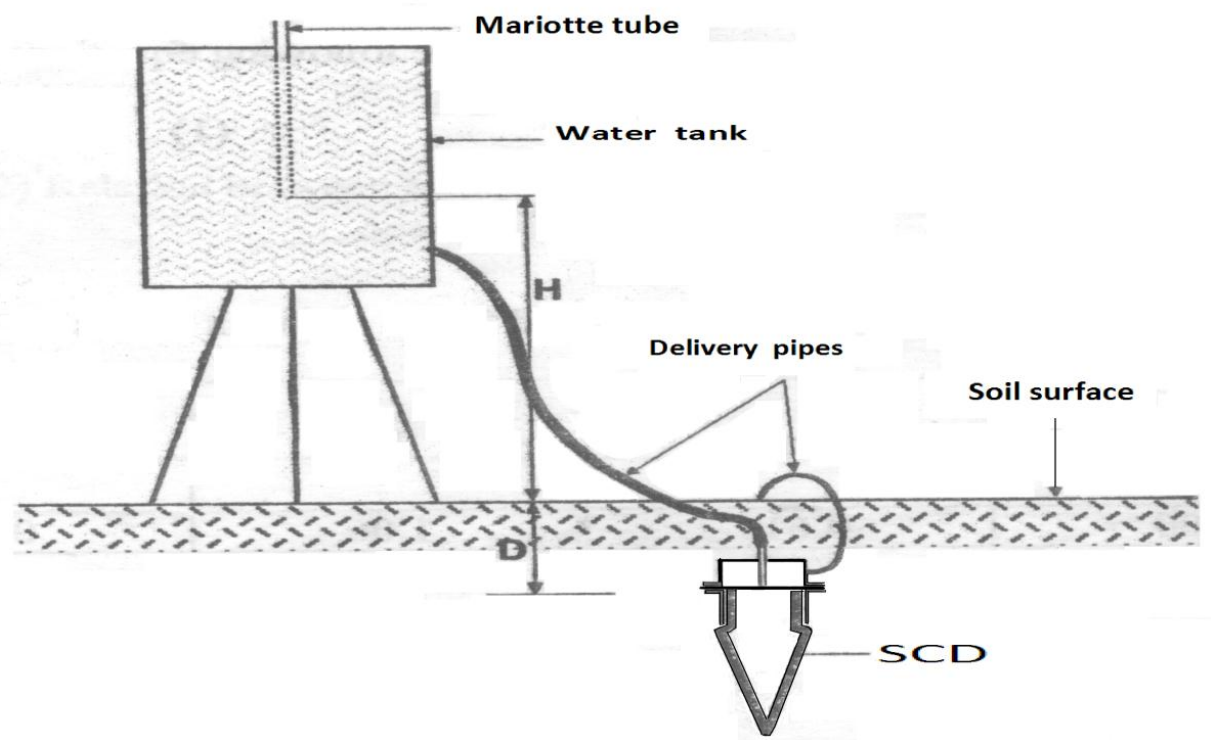

Fig. (2-a) apparatus used in the experiments

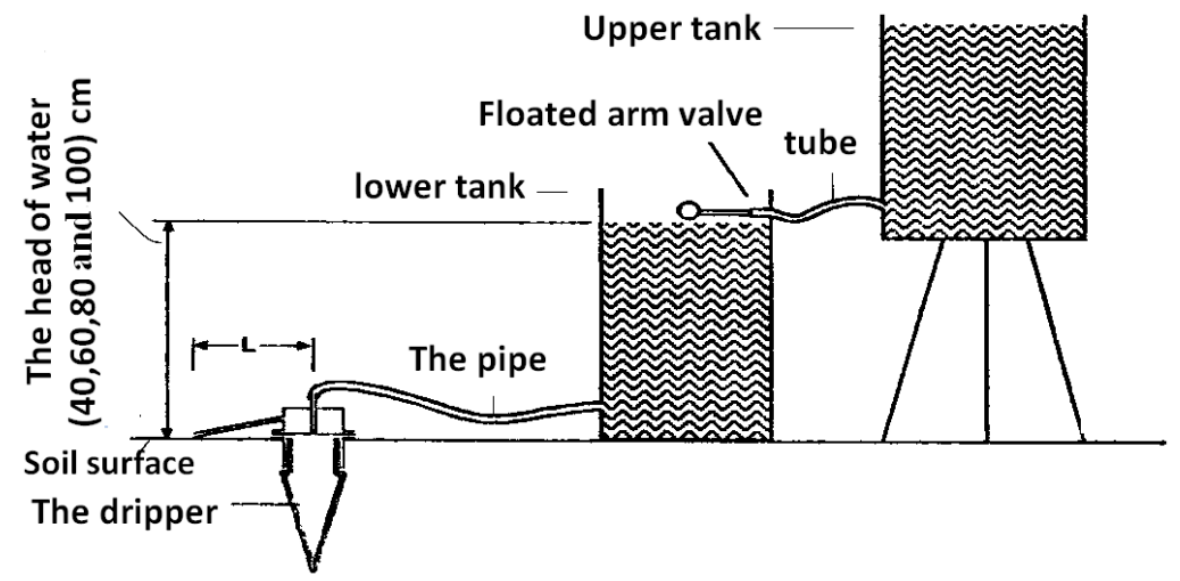

Fig. (2-b) apparatus component which used in the experiments

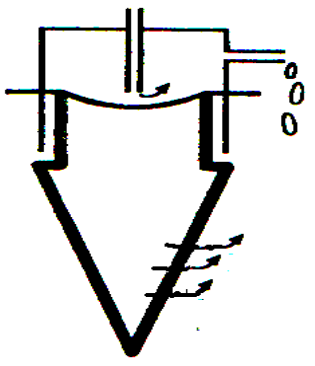

Fig. (3-a) Opened

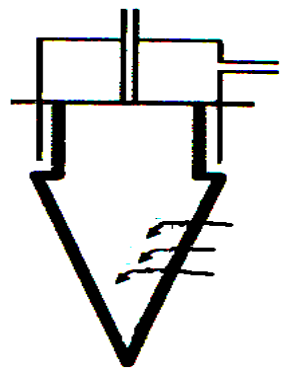

Fig. (3-b) Closed

Fig. (3) Schematic diagram of self control dripper work 
-The laboratory measurement of the Dripper porosity:

1- An amount of water was used more than enough to the volume of the dripper. then the dripper was immersion into the water.then the volume of water was decreased inside the flask due to the porous of the dripper which already were saturated the volume of this pores were calculated as follow:

The volume of the dripper pores $=$ the total volume of the water inside the flask before immersing the dripper and this volume offer immersing the dripper (Abdellatif Z.Y. 2003).

The effect of hydraulic head on the discharge of conical clay jar. -First in air

\begin{tabular}{|c|c|c|c|c|c|c|c|c|c|c|}
\hline $\mathbf{H}(\mathbf{c m})$ & 0 & 10 & 20 & 30 & 40 & 50 & 100 & 150 & 1000 & 1500 \\
\hline $\begin{array}{c}\mathbf{Q} \\
\left(\mathrm{cm}^{3} / \mathrm{hr}\right)\end{array}$ & - & - & - & - & - & - & $\begin{array}{c}1 \\
\mathrm{~cm}^{3} / \mathrm{hr}\end{array}$ & $\begin{array}{c}1 \\
\mathrm{~cm}^{3} / \mathrm{hr}\end{array}$ & $\begin{array}{c}5 \\
\mathrm{~cm}^{3} / \mathrm{hr}\end{array}$ & $\begin{array}{c}10 \\
\mathrm{~cm}^{3} / \mathrm{hr}\end{array}$ \\
\hline
\end{tabular}

The effect of hydraulic head"H"on the discharge of conical clay jar"Q"in dry soil without using"SCD".

\begin{tabular}{|c|c|c|c|c|c|c|}
\hline $\mathrm{H}$ & 20 & 40 & 60 & 80 & 100 & $\mathrm{~cm}$ \\
\hline $\mathrm{Q}$ & 1 & 1.2 & 1.5 & 1.7 & 1.9 & $\mathrm{~cm}^{3} / \mathrm{h}$ \\
\hline
\end{tabular}

\section{2- The soil studied:}

\section{2-1. The physical soil characteristics:}

A- The mechanical analysis was carried out on the sand soil from the from located at EL-6 October city according to the method described by (Richards) 1954.

Table (1) Particle size distribution and texture class of the investigated soils

\begin{tabular}{|c|c|c|c|c|c|}
\hline & \multirow{2}{*}{ Soil depth } & \multicolumn{3}{|c|}{ Particale size distribution } & Textural \\
\cline { 3 - 5 } & $(\mathrm{cm})$ & C. S(\%) & F. S(\%) & silt + clay(\%) & \\
\hline 1 & $0-20$ & 40.74 & 54.79 & 4.47 & sand \\
\hline
\end{tabular}

The moisture characteristics behavior of the sandy soil (PF curves) was determined according to Klute (1965).Then the pore size dist. Were calculated from the PF- curve and presented in table 2 and 3 
Table (2) Soil moisture retention data and soil moisture constants of the investigated soils

\begin{tabular}{|l|c|c|c|c|c|c|c|c|c|}
\hline \multirow{4}{*}{$\begin{array}{c}\text { soil } \\
\text { location }\end{array}$} & \multicolumn{4}{|c|}{$\begin{array}{c}\text { \% Retained moisture (v/v) under } \\
\text { different suctions }\end{array}$} & \multicolumn{4}{c|}{$\begin{array}{c}\text { Soil moisture } \\
\text { constant }\end{array}$} \\
\cline { 2 - 10 } & 0.001 & 0.1 & 0.2 & 0.33 & 1 & 15 & F. C & W. P & AW C \\
\hline 6 October city & 34.5 & 9.66 & 6.54 & 4.19 & 2.48 & 1.59 & 9.66 & 1.59 & 8.07 \\
\hline
\end{tabular}

Table (3): Saturated hydraulic conductivity (Ks), total porosity, pore size distribution (as \% of total) and infiltration rate (IR) of the studied soils.

\begin{tabular}{|c|c|c|c|c|c|c|c|}
\hline & Ks & Total & \multicolumn{3}{|c|}{ pore size distribution (\%) } & I.R \\
\cline { 4 - 7 } Soil location & $(\mathrm{cm} / \mathrm{hr})$ & porosity (\%) & QDP \% & SDP \% & WHP \% & FCP \% & $\mathrm{cm} / \mathrm{hr}$ \\
\hline 6 October city & 7.5 & 34.5 & 72 & 15.8 & 7.54 & 1.59 & 11.8 \\
\hline
\end{tabular}

$\mathrm{QDP}=$ moisture retained between $(0.001-0.1 \mathrm{~atm})(3000-30 \mu)$

$\mathrm{SDP}=$ moisture retained between $(0.1-0.33 \mathrm{~atm})(30-9 \mu)$

WHP $=$ moisture retained between $(0.33-15 \mathrm{~atm})(9-0.2)$

$\mathrm{FCP}=$ moisture retained between at $15 \mathrm{~atm}(<0.2 \mu)$

QDP: quickly drainable pores $\quad$ SDP: slowly drainable pores

WHP: water holding pores $\quad$ FCP: fine capillary pores

\section{RESULTS AND DISCUSSIONS}

There are many factors effect of the performance of the"SCD" "self controller dripper". These factors as operation head, water outlet distance,rubber thickness, buried depth, and sensor volume The relations between them were studied and the relations between them were studied. The relationship between wetness radius of soil"R"and the water outlet length"L"at different rubber thickness"TH"can be shown Fig. (4). The water outlet length has a direct proportional to the wetness radius of soil. From the figure it can be clear that the increase in water outlet length from 10 to $30 \mathrm{~cm}$ the wetness radius of soil increased from 25 to 44, 26 to 43 and 26 to $44 \mathrm{~cm}$ at rubber thickness of 3.0, 3.5 and $4.0 \mathrm{~mm}$ respectively. also, the wetness radius of soil has an inversely proportional to the rubber thickness. From the previous figure shows that the rubber thickness increase from 3.0 to $4.0 \mathrm{~mm}$ cause decrease of wetness radius of soil. On the other hands, Fig. (5) illustrates that effect of sensor volume "V" on wetness radius of soil at different water outlet distance. The figure clear the logically data which the increase in sensor volume 
from 25 to $75 \mathrm{~cm}^{3}$ increase wetness radius of soil from 26, 29, 43 and 24, 27,40 respectively at water outlet distance 10,20 and $30 \mathrm{~cm}$. The same trend found with the increase of water outlet distance from 10 to $30 \mathrm{~cm}$ the wetness radius of soil increase of 24 to 40 and 26 to $43 \mathrm{~cm}$ respectively at sensor volume from 75 to $25 \mathrm{~cm}^{3}$.

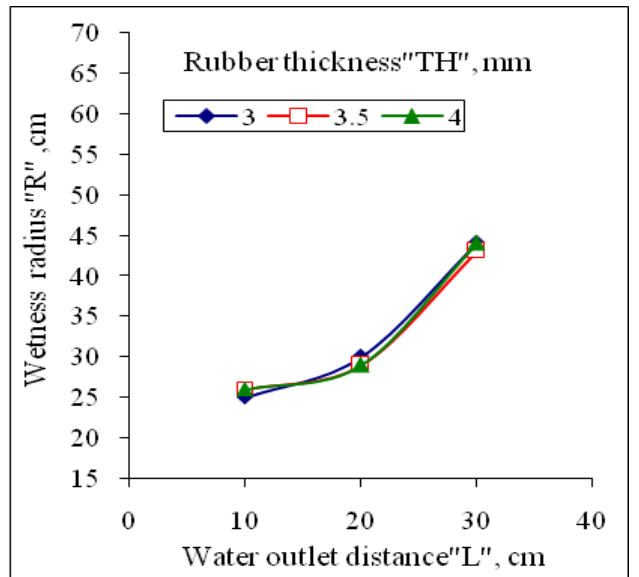

Fig. 4: Effect of water outlet distance on wetness radius at different rubber thickness, head of water $(100 \mathrm{~cm})$, buried depths $(10 \mathrm{~cm})$ and sensor volume $\left(25 \mathrm{~cm}^{3}\right)$

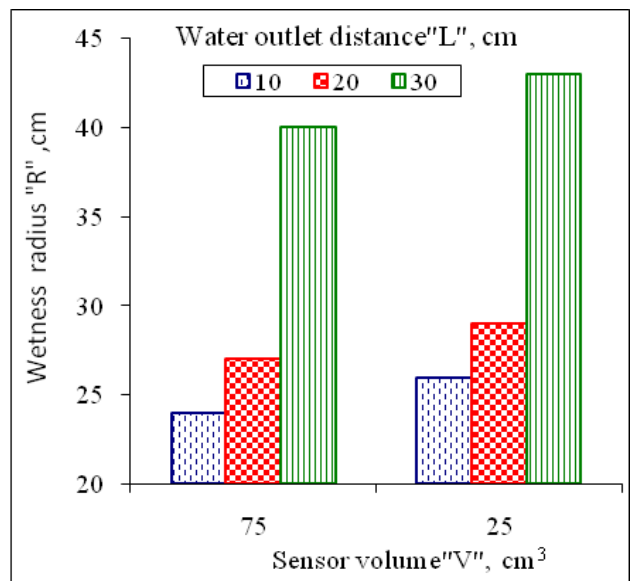

Fig. 5: Effect of sensor volume on wetness radius at different water outlet distance, Head of water $(100 \mathrm{~cm})$, buried depths $(10 \mathrm{~cm})$ and rubber thickness $(3.5 \mathrm{~cm})$

The relationship between wetness radius of soil and the buried depths at different water outlet distance can be shown Fig. (6). The buried depths"D"has a direct proportional to the wetness radius of soil. From the figure it can be clear that the increase in buried depths from 5 to $20 \mathrm{~cm}$ the wetness radius of soil increased from 19 to 38,23 to 43 and 35 to $61 \mathrm{~cm}$ at water outlet distance of 10,20 and $30 \mathrm{~cm}$ respectively. Also, the wetness radius of soil has directly proportional to the water outlet distance. From the previous figure shows that the water outlet distance increase from 10 to 30 $\mathrm{cm}$ cause increase of wetness soil from 19 to 35,26 to 43,33 to 50 and 38 to $61 \mathrm{~cm}$ respectively at buried depths from 5 to $20 \mathrm{~cm}$. Consequently, Fig. (7) clear that effect of head of water on wetness radius of soil at different water outlet distance. The figure clear the data which the increase in head of water from 40 to $100 \mathrm{~cm}$ increase the wetness radius of soil from 18 to $26 ; 22$ to 29 and 31 to $43 \mathrm{~cm}$ respectively at water outlet distance of 10,20 and $30 \mathrm{~cm}$. The same trend found with the increase of water outlet distance from 10 to $30 \mathrm{~cm}$ the wetness radius of soil increase of 18 to 31,21 to 40,23 to 43 and 26 to $43 \mathrm{~cm}$ respectively at head of water from 40 to $100 \mathrm{~cm}$. 


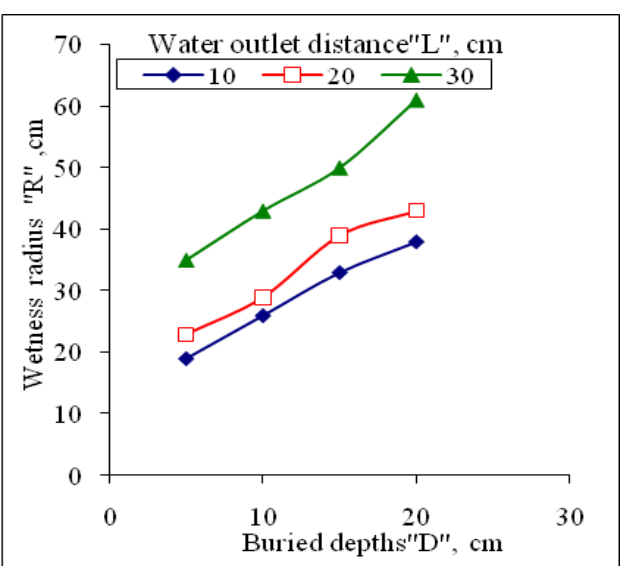

Fig. 6: Effect of buried depths on wetness radius at different water outlet distance, Head of water $(100 \mathrm{~cm})$, sensor volume $\left(25 \mathrm{~cm}^{3}\right)$ and rubber thickness $(3.5 \mathrm{~cm})$

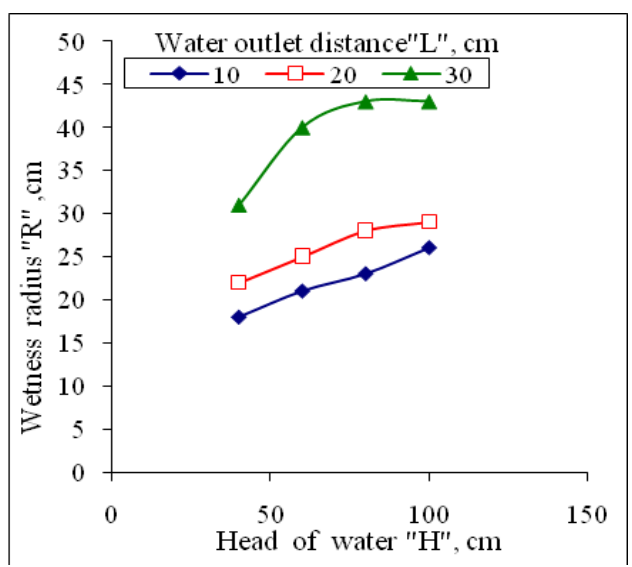

Fig. 7: Effect of head of water on wetness radius at different water outlet distance, sensor volume $\left(25 \mathrm{~cm}^{3}\right) \mathrm{d}$ rubber thickness $(3.5 \mathrm{~cm})$ and buried depths $(10 \mathrm{~cm})$

The relationship between adding water and the water outlet distance at different rubber thickness can be shown Fig. (8). The water outlet distance has a direct proportional to the adding water. From the figure it can be clear that the increase in rubber thickness of 3.0, 3.5 and $4.0 \mathrm{~mm}$ the adding water soil decreased from 9.2 to $8.5,18.2$ to 12.4 and 56.6 to $49.9 \mathrm{~cm}$ respectively at water outlet distance from 10,20 and $30 . \mathrm{cm}$. Also, the adding water soil has an inversely proportional to the water outlet distance. From the previous figure shows that the water outlet distance increase from 10 to $30 \mathrm{cmm}$ cause decrease of adding water soil from 9.2 to $65.6,10.7$ to 62.4 and 8.5 to $49.9 \mathrm{~cm}$ respectively. On the other hands, Fig. (9) illustrate that effect of sensor volume on adding water soil at different water outlet distance. The figure clear the logically data which the increase in sensor volume from 25 to $75 \mathrm{~cm}^{3}$ decrease the adding water soil from 10.7 to $8.3,15.612$ and 62.4 to $48 \mathrm{~L}$ respectively at water outlet distance 10,20 and $30 \mathrm{~cm}$. The same trend found with the increase of water outlet distance from 10 to $30 \mathrm{~cm}$ the adding water soil increase 10.7 to 62.4 and 8.3 to $48 \mathrm{~L}$ respectively.

The relationship between adding water and the buried depths at different water outlet distance can be shown Fig. (10). The buried depths has a direct proportional to the adding water soil. From the figure it can be clear that the increase in buried depths from 5 to $20 \mathrm{~cm}$ the adding water increased from 3.3 to $41.6,7.2$ to 64 and 30.8 to $208 \mathrm{~L}$ respectively at 
water outlet distance of 10,20 and $30 \mathrm{~cm}$. Also, the adding water has directly proportional to the water outlet distance. From the previous figure shows that the water outlet distance increase from 10 to $30 \mathrm{~cm}$ cause increase adding water of soil from 3.3 to $30.8,10.7$ to $62.4,24$ to 105 and 41.6 to $208 \mathrm{~L}$ respectively. Consequently, Fig. (11) clear that effect of Head of water on adding water at different water outlet distance. The figure clear the data which the increase in Head of water from 40 to 100 $\mathrm{cm}$ increase the adding water from 2.8 to $10.7,6.1$ to 15.6 and 19.5 to 62.4 $L$ respectively at water outlet distance 10,20 and $30 \mathrm{~cm}$.

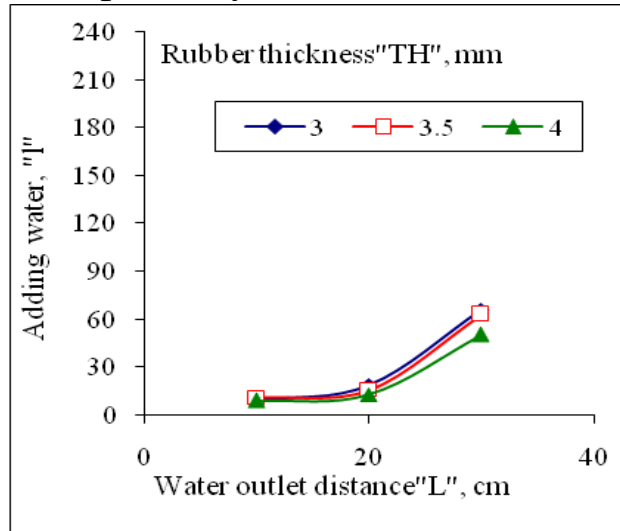

Fig 8: Effect of water outlet distance on adding water at different rubber thickness, head of water $(100 \mathrm{~cm})$, sensor volume $\left(25 \mathrm{~cm}^{3}\right)$ and buried depths $(10 \mathrm{~cm})$

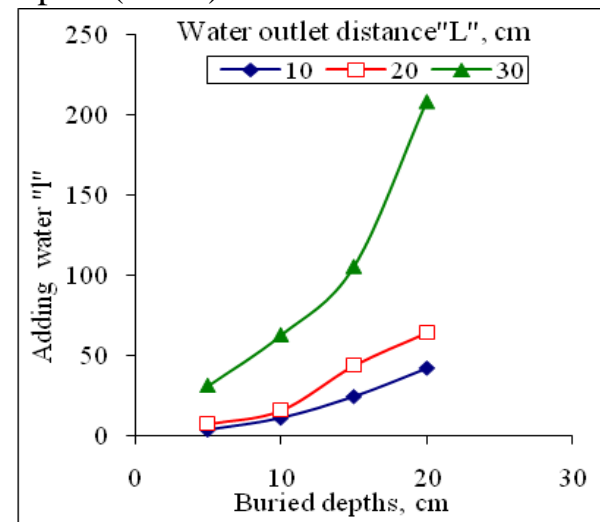

Fig.10: Effect of buried depths on adding water at different water outlet distance head of water $(100 \mathrm{~cm})$,sensor volume $\left(25 \mathrm{~cm}^{3}\right)$ and rubber thickness $(3.5 \mathrm{~cm})$

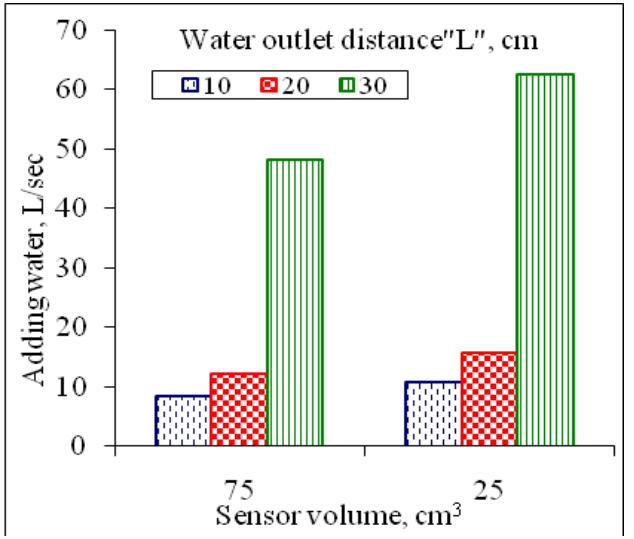

Fig. 9: Effect of sensor volume on adding water at different water outlet distance, head of water $(100 \mathrm{~cm})$, buried depths $(10 \mathrm{~cm})$ and rubber thickness $(3.5 \mathrm{~cm})$

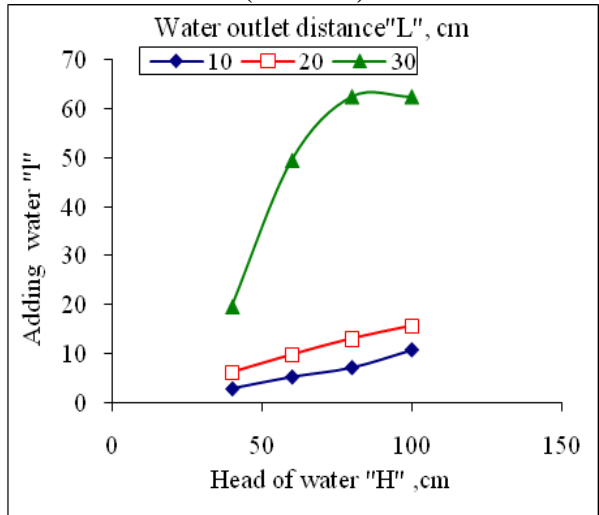

Fig. 11: Effect of head of water $\mathrm{H}$ ", cm on adding water at different water outlet distance, buried depths $(10 \mathrm{~cm})$, sensor volume $\left(25 \mathrm{~cm}^{3}\right)$ and rubber thickness $(3.5 \mathrm{~cm})$ 
The relationship between opening time and the water outlet length at different rubber thickness can be shown Fig. (12). The water outlet distance has a direct proportional to the opening time. From the figure it can be clear that the increase in water outlet distance from 10 to $30 \mathrm{~cm}$ the opening time increased from 16 to 93,12 to 93 and 12 to $93 \mathrm{~min}$ respectively at rubber thickness of $3.0,3.5$ and $4.0 \mathrm{~mm}$. Also, the opening time has an inversely proportional to the rubber thickness. From the previous figure shows that the rubber thickness increase from 3.0 to $4.0 \mathrm{~mm}$ cause decrease of opening time from 16 to 12,76 to $72 \mathrm{~min}$ respectively.

On the other hands, Fig. (13) illustrates that effect of sensor volume on opening time at different water outlet distance. The figure clear the logically data which the increase in sensor volume from 25 to $75 \mathrm{~cm}^{3}$ increase the opening time from 12 to 15,72 to 85 and 93 to $110 \mathrm{~min}$ respectively at water outlet distance 10,20 and $30 \mathrm{~cm}$. The same trend found with the increase of water outlet distance from 10 to $30 \mathrm{~cm}$ the opening time increase 12 to 93,15 to 110 min respectively.

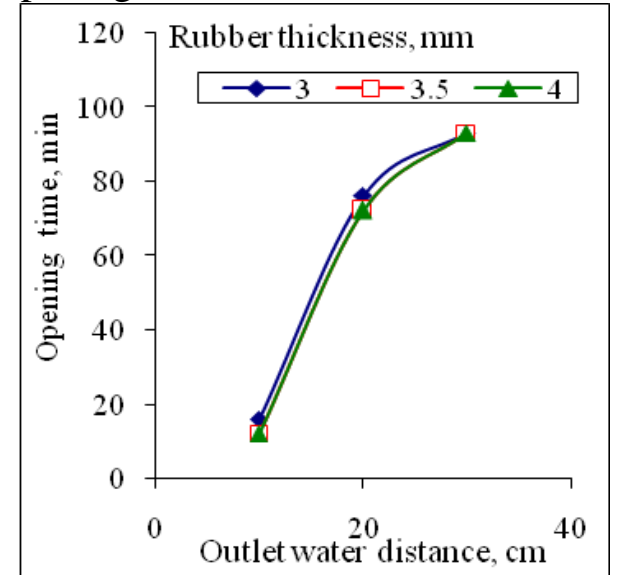

Fig. 12: Effect of water outlet distance on opening time at different rubber thickness, Head of water $(100 \mathrm{~cm})$, buried depths $(10 \mathrm{~cm})$ and sensor volume $\left(25 \mathrm{~cm}^{3}\right)$

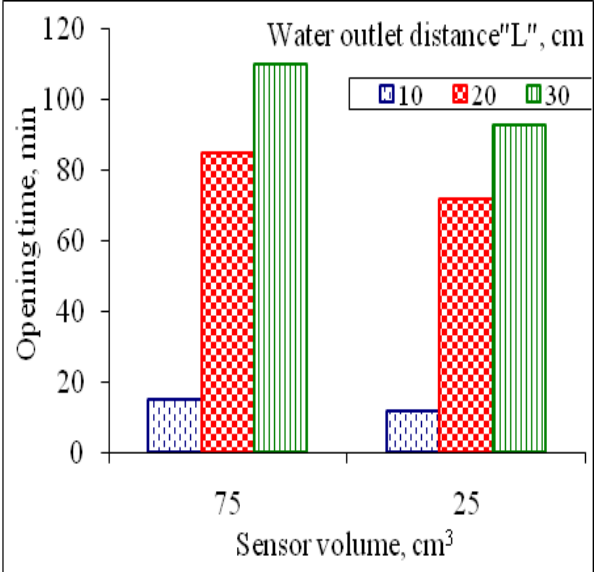

Fig. 13: Effect of sensor volume on opening time at different water outlet distance, Head of water $(100 \mathrm{~cm})$, buried depths $(10 \mathrm{~cm})$ and rubber thickness $(3.5 \mathrm{~cm})$

The relationship between opening time and the buried depths at different water outlet distance can be shown Fig. (14). The buried depths has a direct proportional to the opening time. From the figure it can be clear 
that the increase in buried depths from 5 to $20 \mathrm{~cm}$ the opening time increased from 7 to 19,52 to 70 and 76 to $98 \mathrm{~min}$ respectively at water outlet distance of 10, 20 and $30 \mathrm{~cm}$. Also, opening time has directly proportional to the water outlet distance. From the previous figure shows that the water outlet distance increase from 10 to $30 \mathrm{~cm}$ cause increase of opening time from 7 to 76,12 to 93,15 to 104 and 19 to $98 \mathrm{~min}$ respectively. Consequently, Fig. (15) clear that effect of head of water on opening time at different water outlet distance. The figure clear the data which the increase in head of water from 40 to $100 \mathrm{~cm}$ decrease the opening time from 19 to 12,85 to 72 and 103 to 93 min respectively at water outlet distance of 10,20 and $30 \mathrm{~cm}$. The same trend found with the increase of water outlet distance from 10 to $30 \mathrm{~cm}$ the opening time increase of 19 to 103,17 to 102,12 to 85 and 12 to 93 min respectively.

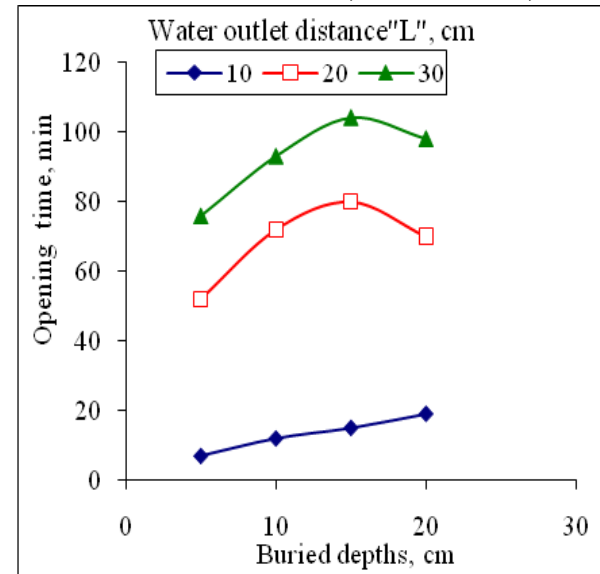

Fig. 14: Effect of buried depths on opening time at different water outlet distance, sensor volume $(25$ $\left.\mathrm{cm}^{3}\right)$,Head of water $(100 \mathrm{~cm})$, and rubber thickness $(3.5 \mathrm{~cm})$

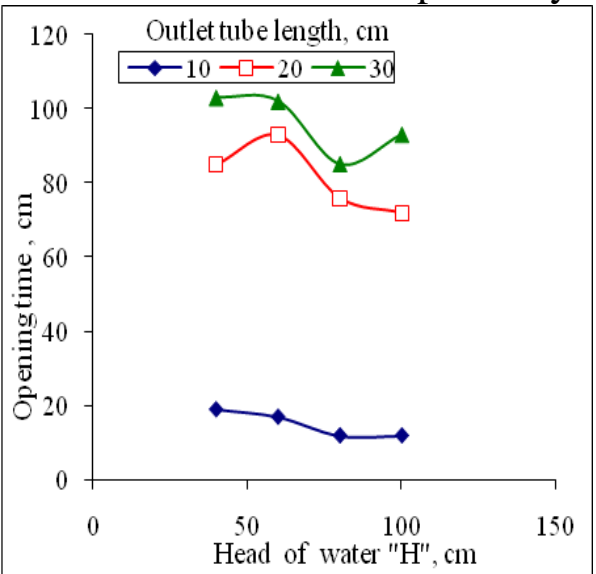

Fig. 15: Effect of head of water on wetness radius of soil at different water outlet distance. sensor volume $\left(25 \mathrm{~cm}^{3}\right)$, buried depths $(10 \mathrm{~cm})$, and rubber thickness $(3.5 \mathrm{~cm})$

Also by ANOVA TEST by correlation Analysis that joined between multi variable. We can obtained three general equation joined between multi variable:

The relation between quantity of water adding, buried depths, head of water, water outlet distance, rubber thickness, and sensor volume were as in the following equation: 


$$
\mathrm{Q}=\left(5.6 \times 10^{-4}\right)\left(\frac{D^{1.3928} * H^{1.303} * L^{1.656}}{T H^{2.061} * V^{.271}}\right)
$$

lit

The relation between wetness radius of soil, buried depths, head of water, water outlet distance, rubber thickness, and sensor volume were as in the following equation

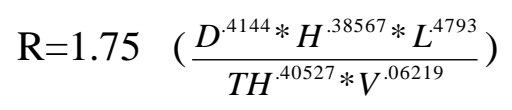

cm

The relation between opining time of dripper, buried depths, thickness of rubber, water outlet distance, volume of sensor, wetness radius, and the head of water were as in the following equation:

$$
\mathrm{T}=0.159 \quad\left(\frac{D^{.5405} * T H^{.40527} * L^{1.835} * V^{.2553}}{H^{.46922}}\right)
$$

$\min$

Where: TH : Rubber thickness, $\mathrm{mm}, \quad \mathrm{V}:$ Sensor volume, $\mathrm{cm}^{3}$,
D: Buried depths, cm,
$\mathrm{H}$ : Operation heads, $\mathrm{cm}$,

$\mathrm{L}$ : length of the outlet tube, $\mathrm{cm}, \mathrm{R}$ : Radius of wetness soil area, $\mathrm{cm}$,

$\mathrm{Q}$ : Water outflows, lit,

$\mathrm{T}$ : opining time of dripper, min.

Figs. $(16,17,18)$ show the relation between"Q",'R"and"T"measured and calculated by equation 1,2 and 3 respectively.

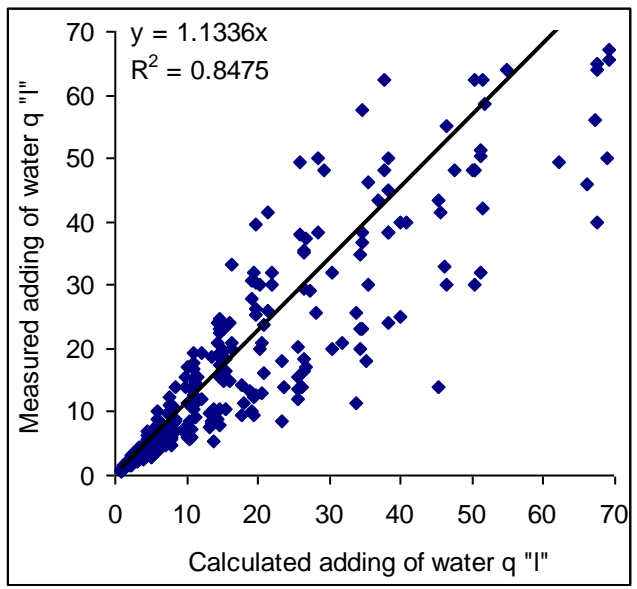

Fig. 16: relation between measured adding water"q"and calculated adding water"q"

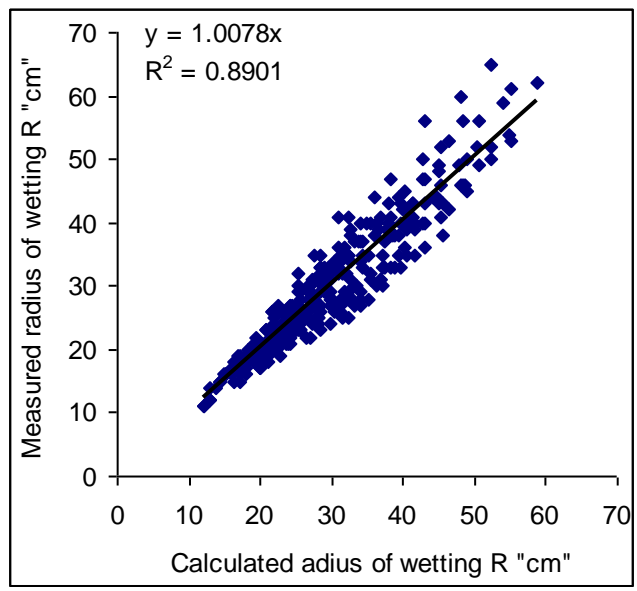

Fig. 17: relation between measured radius of wetting" $R$ "and calculated radius of wetting" $R$ " 


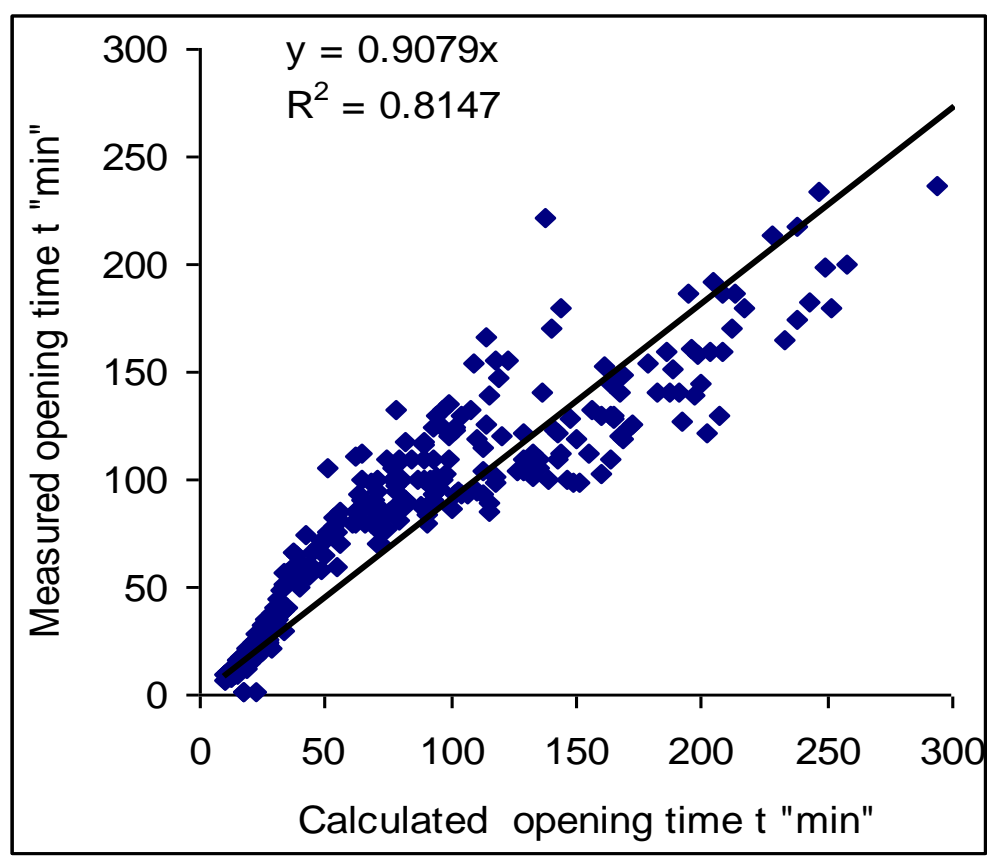

Fig. 18: Relation between measured opening time " $t$ " and calculated opening time"t".

\section{Features of self-controller dripper:}

1) Does not require external power source to control where it is influenced by soil hard to open and lock which opens at -25 to -30 centibar and closes at -7 centibar

2) Does not require high pressures to operate, which saves in the energy used.

3) Has the ability to control the amount of water discharged by controlling the length of the exit

4) The cost of production of small

5) Eliminates the loss in the amount of irrigation water, which increases efficiency

6) Needs to be smaller in diameter branch lines and because the water is followed by a sustained basis, which provides the costs of establishing the network 
The results of the experiments clarified that the adding water"quantity of water Q"flowing from the dripper, the opening time, and the mean diameter of $\mathrm{L}$ wetting increased with increasing the outlet distance of the dripper. The relationship between them was fitted in the following equation

\section{Recommendations}

This new self-controller dripper prefers to use for sandy soils and can be used to any crops.

In case of using it to irrigate trees, it is good to use outlet with distributer more fine to increase the wetness area specially, for the sandy soil.

\section{REFERENCES}

Abdellatif Z.Y. (2003). A study on self-controlled dripper (effect of outlet distance on water flow), Misr J.Ag.Eng., 20(1).

Deleenheer,L.,And Beboodt, M 1965., Soil Analysis.international raining center., post gradual. Soil sci. Gent,Belgium.

David A. Bainbridge (2001) Buried clay pot irrigation: a little known but very efficient traditional method of irrigation -Agricultural Water Management, Volume 48, Issue 2, June 2001, Pages 79-88

D.M. Ibrahim, D.A.; Abd EL Aziz, A. Awad, A.M. Abdel Monem Ceramic Department, National Research centre, Dokki,Giza, Egypt Geology Department, Received 15 April 2003; received in revised from 25 May 2003; accepted 2 September 2003 - Available online 21 March 2004.

Klute, A. (1965). Methods of soil Analysis. part 1. As monograph No.9: 210-233. Medison, Wiscansin.

Ornstein, L. (1985) The Irristat: A moisture - sensitive regulating water valve for drip irrigation systems. Proceedings of the third International Drip/Trickle Irrigation Congress: 623-629.

Richards, L.A. (1954). Diagnosis and improvement of saline and alkali soils. USDA. Agricultural handbook 60, Washington, 160p. 


\section{الملخص العربي \\ تصميم وتقييم نقاط ذاتى التحكم}

المسيري. ع.ع*، ز.عبد اللطيف***، س. حسن******** أ.عبد الرشيد

تهذف هذه الدر اسة إلي تصميم وتقييم نقاط ذاتي التحكم "SCD“للتحكم في إدارة المياه في التربة

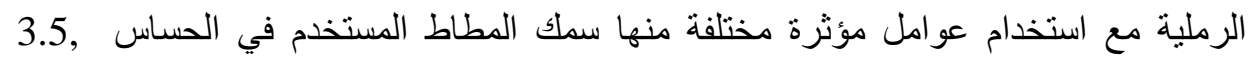

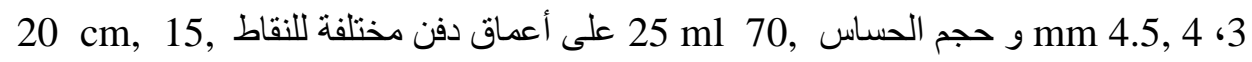

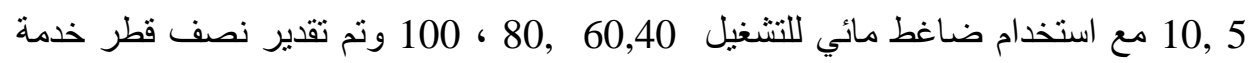
النقاط R ومعدل إضافة المياه باللترQ وزمن إضافة الماء بالدقيقة T و وتم الحصول على النتائج لأفضل أداء للنقاط بتقدير أفضل قطر خرطوم مستخدم وكان 2 mm كذللك أفضل حجم للحساس وكان 25 ml وأفضل سمك للمطاط يقع بين 3.5 و 4 mm 4 تم ربط هذه العوامل مع وكع نصف قطر البلل R وزمن فتح النقاط T و كمية المياه Q وكانت كالاتى : $\mathrm{R}=1.75\left(\frac{D^{.4144} * H^{.38567} * L^{.4793}}{T H^{.40527} * V^{.06219}}\right)$

mm، حيث : بعد مخرج الخرطوم عن الحساس، Th cm : سمك الحساس

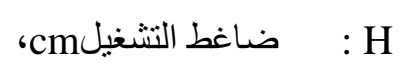
cm² :V

cm ، نصف قطر البلل في التربة : R cm , عمق الدفن : D

* أستاذ الهندسة الزراعية كلية الهندسة الزراعية جامعة الأزهر بالقاهرة.

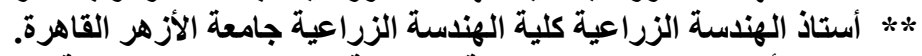

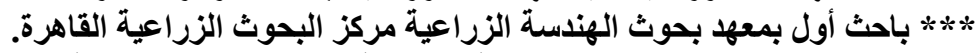

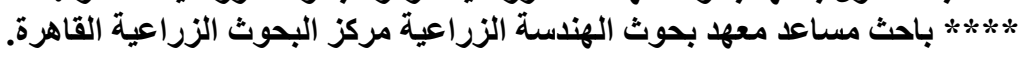

